УДК 343.985

DOI https://doi.org/10.32844/2618-1258.2019.3-2.32

НЕЧВАЛЬ А.О.

\title{
ОСОБЛИВОСТІ ВИКОРИСТАННЯ СПЕЦАЛЬНИХ ЗНАНЬ НА ПІДГОТОВЧОМУ ЕТАПІ ОБШУКУ
}

Стаття присвячена окремим питанням, що стосуються особливостей використання спеціальних знань на підготовчому етапі обшуку. У контексті розкрито ключові наукові положення криміналістики, кримінального процесу, проаналізовано чинне кримінальне процесуальне законодавство, що надає можливість повною мірою зрозуміти та оцінити досліджувану проблематику. Наголошено, що важливим елементом підготовки до обшуку житла чи іншого володіння особи $є$ початковий непроцесуальний огляд прилеглої території, під’їздів, вхідних дверей об'єкта обшуку. Водночас компетенції слідчого не досить, аби встановити вид дверного замка, можливі способи його відкриття, спеціальне обладнання, що може знадобитися, та інше. 3'ясовано, що під час підготовки до обшуку слідчий повинен зібрати всю можливу інформацію про власника житла чи особу, що займає приміщення, зокрема, щодо наявності вогнепальної зброї; належності до Операції Об'єднаних сил, до військової справи; наявності спеціальних знань щодо вибухотехніки; причетності у минулому до кримінальних правопорушень тощо. Визначено, що у разі встановлення достатніх даних, що на об'єкті обшуку є факти порушень правил або незаконного поводження з радіоактивними, хімічними та ядерними матеріалами, слідчий зобов'язаний негайно вжити заходів щодо індивідуальної та публічної безпеки, недопущення подальшого контакту людей і тварин із ними та в обов'язковому порядку повідомити оперативного чергового по органу. Зроблено висновок про доцільність внести до чинного Кримінально-процесуального кодексу (далі - КПК) норму щодо можливості дистанційної участі понятих під час обшуку за допомогою застосування технічних засобів фіксації у режимі відеоконференції у разі виникнення потенційної загрози для їхньої особистої безпеки. 3 погляду криміналістичної тактики алгоритм дій керівника слідчо-оперативної групи (далі - СОГ) матиме такий вигляд: 1) після виявлення підозрілих предметів, перш за все, організувати евакуацію всіх учасників обшуку та забезпечити схоронність місця події; 2) 3 прибуттям спеціалістів забезпечити звуко- та відеофіксацію процесу виявлення, пакування та вилучення потенційно небезпечних об'єктів із дистанційним транслюванням на технічних носіях для пред'явлення понятим. Запропоновано ключові положення вирішення актуальних питань.

Ключові слова: обшук, слідчі (розшукові) дї, спечіаліст, підготовчий етап, спеціальні знання, форми взаємодії, криміналістична техніка.

The article deals with specific issues related to the peculiarities of the use of specialized knowledge at the preparatory stage of the search. In the context, the key scientific provisions of criminalistics, the criminal process are revealed, the current criminal procedural legislation is analyzed, which gives an opportunity to fully understand and evaluate the investigated problems. It is emphasized that an important element of preparation for a search of a dwelling or other possession of a person is the initial nonprocedural inspection of the surrounding area, entrances, entrance doors of the object of the search. However, the competence of the investigator is not sufficient to establish the type of door lock, possible ways to open it, special equipment that may be needed, and so on. It is found that, in preparation for the search, the investigator must collect all possible information about the homeowner or occupier, including the availability of a firearm;

(C) НЕЧВАЛЬ А.О. - ад’юнкт кафедри криміналістики та судової медицини (Національна академія внутрішніх справ) 
affiliation to the United States Operation, to the military; availability of specific knowledge of explosives; past involvement in criminal offenses and the like. It is determined that in case of sufficient data establishment, the investigator is obliged to assume that the object of the search is violations of the rules or illegal handling of radioactive, chemical and nuclear materials, to take immediate measures regarding individual and public safety, preventing further contact of people and animals with them, and without fail to notify the operative duty on the body. It is concluded that it is advisable to introduce a standard in the CCP concerning the possibility of remote participation of the witnesses during the search, by using technical means of videoconference fixing, in case of potential threat to their personal safety. From the point of view of forensic tactics, the algorithm of actions of the head of the FOG will look as follows: 1) detecting suspicious objects, first of all to organize the evacuation of all participants of the search and to ensure the security of the scene; 2) with the arrival of specialists, to provide sound and video fixation of the process of detection, packaging and removal of potentially dangerous objects, with remote broadcasting on technical media for presentation to understand. Key provisions for solving topical issues are proposed.

Key words: search, investigative (search) actions, specialist, preparatory stage, special knowledge, forms of interaction, forensic equipment.

Вступ. Доцільність використання спеціальних знань під час розслідування кримінальних правопорушень зумовлена не лише структурою сучасної злочинної діяльності, а й розвитком нових підходів в організації взаємодії органів і підрозділів кримінальної юстиції з відповідними судово-експертними установами, а в окремих випадках - з фізичними або юридичними особами, які можуть бути залучені у сферу кримінальних процесуальних відносин як спеціалісти під час проведення окремих слідчих (розшукових) дій.

У криміналістичній літературі вже зверталась увага на те, що завдяки спеціальним знанням можливо відкрити нові джерела доказової інформації, на підставі якої висуваються слідчі версії, визначається напрям розслідування, встановлюються особа злочинця, мета, мотив і механізм вчинення злочину [7, с. 64].

Постановка завдання. Метою статті є розгляд окремих питань, що стосуються особливостей використання спеціальних знань під час обшуку, а також тактико-криміналістичних прийомів на підготовчому етапі його проведення.

Аналіз останніх досліджень і публікацій. Проблематиці використання спеціальних знань у кримінальному провадженні присвятили свої праці відомі вчені-криміналісти, такі як: Ю.П. Аленін, Р.С. Бєлкін, А.І. Вінберг, В.Г. Гончаренко, О.О. Ейсман, В.А. Журавель, Н.І. Клименко, В.В. Коваленко, В.С. Коновалова, В.М. Махов, В.О. Образцов, О.Р. Ратинов, О.Р. Росинська, М.В. Салтевський, В.Ю. Шепітько, М.Г. Щербаковський, М.П. Яблоков та інші.

Результати дослідження. У кримінальній процесуальній та криміналістичній літературі пропонуються різні підстави для класифікації форм використання спеціальних знань. Наприклад, М.Г. Щербаковський та О.А. Кравченко класифікують їх залежно від доказового значення результатів їх застосування (процесуальні і непроцесуальні); суб'єкта доказування (безпосередня і опосередкована); процесуального становища суб'єктів використання спеціальних знань [11, с. 51]. Н.I. Клименко пропонує такі критерії для відокремлення форм використання спеціальних знань: а) за нормативною регламентацією (процесуальні і непроцесуальні); б) за процесуальним статусом осіб, що володіють спеціальними знаннями (слідчий, експерт, спеціаліст, консультант); в) за процесуальною формою реалізації (судові експертизи, участь спеціаліста, участь консультанта); г) за змістом [10, с. 141]. У контексті вищевказаної теми ми зупинимось на двох основних формах: за процесуальним статусом учасників кримінального провадження та за нормативною регламентацією.

Зважаючи на сучасну практичну діяльність органів досудового розслідування Національної поліції України, на підготовчому етапі обшуку, як правило, використовуються спеціальні знання, якими володіють: інспектори-криміналісти (техніки-криміналісти); працівники Експертної служби МВС у складі спеціалізованої пересувної лабораторії; спеціалісти-вибухотехніки працівники органів внутрішніх справ, виконання обов'язків яких пов'язано 3 поводженням із вибуховими матеріалами [2]; працівники підрозділів Державної служби України з надзвичайних ситуацій (далі - ДСНС) та інші. 
Що стосується форм використання спеціальних знань за нормативною регламентацією, то на підготовчому етапі обшуку більшість із них $\epsilon$ непроцесуальними, що надає змогу органам досудового розслідування побудувати можливі слідчі ситуації, а також визначити тактику його проведення.

На підготовчому етапі обшуку слідчі, як правило, використовують такі непроцесуальні форми взаємодії:

- усну консультативну допомогу, яка має тільки орієнтуюче значення під час розслідування кримінального провадження;

- роз'яснення з приводу термінології, що використовується в окремій галузі знань, правильних назв об'єктів або їхніх частин, які підлягатимуть вилученню;

- консультації щодо особливостей вилучення, пакування, перевезення та збереження потенційно небезпечних речовин як предметів обшуку;

- довідки, роз'яснення зі спеціальних питань, що можуть виникнути або виникають під час підготовки та проведення слідчих (розшукових) дій, процесуального оформлення їхніх результатів тощо.

У свою чергу, до процесуальних форм взаємодії належать такі:

- направлення листа до відповідного відомства щодо необхідності залучення спеціалістів для проведення обшуку з урахуванням його специфіки;

- отримання висновків експерта, які надалі виступатимуть як докази під час формування клопотань про обшук;

- клопотання спеціаліста з приводу необхідності долучення документів, речових доказів для повноти експертного дослідження, що можливо отримати під час обшуку;

- письмові роз'яснення, довідки зі спеціальних питань, що можуть виникнути під час підготовки до обшуку тощо.

Важливим елементом підготовки до обшуку житла чи іншого володіння особи є початковий непроцесуальний огляд прилеглої території, під'їздів, вхідних дверей об'єкта обшуку. Водночас компетенції слідчого не досить, аби встановити вид дверного замка, можливих способів його відкриття, спеціального обладнання, що може знадобитися, та іншого. У такому разі оперативні працівники залучають до огляду спеціалістів, які проводять фотофіксацію, встановлюють необхідні дані у разі необхідності примусового відкриття дверей і фіксують це у протоколі огляду. Такі дії спеціаліста також можна віднести до процесуальної форми взаємодії із слідчим на початковому етапі обшуку.

Варто зазначити, що в сучасній практичній діяльності органів досудового розслідування Національної поліції України джерелами, з яких отримується інформація про доцільність обшуку, $€$ відомості, отримані під час негласних слідчих (розшукових) дій, зокрема: аудіо-, відеоконтроль особи (ст. 260 КПК), накладення арешту на кореспонденцію (ст. 261 КПК), зняття інформації 3 транспортних телекомунікаційних мереж (ст. 263 КПК), зняття інформації з електронних інформаційних систем (ст. 264 КПК), обстеження публічно недоступних місць, житла чи іншого володіння особи (ст. 267 КПК), установлення місцезнаходження радіоелектронного засобу (ст. 268 КПК), спостереження за особою, річчю або місцем (ст. 269 КПК), аудіо-, відеоконтроль місця (ст. 270 КПК).

Під час підготовки до обшуку слідчий повинен зібрати всю можливу інформацію про власника житла чи особу, що займає приміщення, зокрема, щодо такого: наявності вогнепальної зброї; належності до Операції Об'єднаних сил, до військової справи; наявності спеціальних знань щодо вибухотехніки; причетності у минулому до кримінальних правопорушень тощо. Ці відомості допоможуть побудувати слідчі версії з урахуванням усіх можливих ситуацій під час обшуку. У разі встановлення фактів, що вказують на наявність на місці обшуку вибухових пристроїв або речовин, слідчому необхідна допомога саме спеціалістів-вибухотехніків. Ними здійснюються пошук, експертний огляд, розрядження, транспортування та знешкодження вибухових пристроїв і вибухових речовин (проводяться спеціальні вибухотехнічні роботи) [2].

Під час обшуку житла чи іншого володіння особи виникають найрізноманітніші слідчі ситуації, зумовлюючи необхідність використання спеціальних знань різних галузей. Часто компетенції та повноважень слідчого, інспектора-криміналіста не досить для їх вирішення. На практиці, зокрема під час обшуку, часто виникає необхідність у залученні підрозділів Державної служби з надзвичайних ситуацій (далі - ДСНС). Проте чинним кримінальним процесуальним законодавством не врегульовано питання з приводу форм взаємодії ДСНС та Національної поліції під час обшуку. Наукові кримінальні процесуальні та криміналістичні джерела також залишають поза увагою використання цього виду спеціальних знань. 
Процесуальний порядок залучення підрозділів ДСНС із метою відкриття житла чи іншого володіння особи не врегульовано повною мірою. На нашу думку, найчастіше перешкоджання законному проникненню під час обшуку зазвичай здійснюється власниками, особами, присутніми під час обшуку, які відмовляються відкривати закрите приміщення, сховище, порушуючи ч. 6 ст. 236 КПК України. За таких умов приміщення, як правило, відкривається спеціалістами, а в окремих випадках - працівниками ДСНС.

3 погляду криміналістичної тактики залучення працівників ДСНС варто планувати саме на підготовчому етапі обшуку. Важливу роль у цьому процесі відіграє інформація, надана оперативним працівниками, щодо можливих варіантів проникнення слідчо-оперативної групи (далі СОГ) до житла чи іншого володіння особи. У разі встановлення необхідності використання спеціальних знань слідчий, визначившись із датою та часом проведення обшуку, завчасно надсилає лист до відповідного територіального підрозділу ДСНС із коротким викладом обставин. Формуючи зміст звернення, варто пам'ятати про необхідність дотримання таємниці досудового розслідування, зокрема, що стосується адреси, власника житла чи іншого володіння особи тощо. Саме тому, на нашу думку, найдоцільнішим місцем збору СОГ і працівників ДСНС є орган досудового розслідування.

У разі встановлення достатніх даних, що на об’єкті обшуку є факти порушень правил або незаконного поводження з радіоактивними, хімічними та ядерними матеріалами, слідчий зобов'язаний негайно вжити заходів щодо індивідуальної та публічної безпеки, недопущення подальшого контакту людей і тварин із ними та в обов'язковому порядку повідомити оперативного чергового по органу. Оперативний черговий інформує територіальні органи ДСНС або підпорядковані їм підрозділи, а також територіальні органи (підрозділи) СБУ, Держекоінспекції, Держпродспоживслужби, Держатомрегулювання, місцеві державні адміністрації та органи місцевого самоврядування [8, с. 36].

До приїзду аварійно-рятувальних служб і фахівців заінтересованих органів державної влади, що залучаються в кожному конкретному випадку, поліцейські, які прибули першими до місця події, проводять такі першочергові дії:

1) евакуюють людей із зони можливого ураження на мінімальну безпечну відстань (приблизно 100-400 м) в напрямку, протилежному напрямку вітру, з урахуванням географічного розташування місця події, кліматичних умов, характеру місцевості та/або особливостей водного простору, наявності будівель та/або споруд, закритого простору, потенційних об'єктів ураження тощо;

2) уживають заходів для надання невідкладної, зокрема домедичної, допомоги особам, які постраждали внаслідок ураження небезпечними матеріалами та викликають медичних працівників до місця події для надання медичної допомоги, а також за можливості інформують членів сім'ї потерпілих;

3) організовують огородження зони можливого ураження та встановлюють попереджувальні знаки, зокрема, для транспортних засобів, а також забезпечують безпеку дорожнього руху;

4) забезпечують публічну безпеку та порядок навколо зони можливого ураження, недопущення контакту людей та тварин із місцем виявлення підозрюваного об'єкта;

5) здійснюють інші заходи для забезпечення безпеки громадян і довкілля, передбачені законодавством України [3].

Вартою уваги є тактика проведення обшуку під час раптового виявлення вибухових пристроїв, радіоактивних, хімічних та ядерних матеріалів тощо, зокрема, щодо забезпечення особистої безпеки учасників обшуку. Відповідно до п. 2 ч. 7 ст. 223 КПК, обшук житла чи іншого володіння здійснюється 3 обов'язковою участю не менше двох понятих незалежно від застосування технічних засобів фіксування. Водночас керівник СОГ у разі виявлення підозрілих предметів, перш за все, повинен організувати евакуацію всіх учасників обшуку та забезпечити схоронність місця події до прибуття спеціальних служб. У такому разі постає питання з приводу забезпечення безпосередньої участі понятих під час виявлення та вилучення небезпечних об'єктів.

На нашу думку, варто внести до чинного КПК норму щодо можливості дистанційної участі понятих під час обшуку за допомогою застосування технічних засобів фіксації у режимі відеоконференції у разі виникнення потенційної загрози для їхньої особистої безпеки. 3 погляду криміналістичної тактики алгоритм дій керівника СОГ матиме такий вигляд: 1) після виявлення підозрілих предметів, перш за все, організувати евакуацію всіх учасників обшуку та забезпечити схоронність місця події; 2) з прибуттям спеціалістів забезпечити звуко- та відеофіксацію процесу виявлення, пакування та вилучення потенційно небезпечних об'єктів із дистанційним транслюванням на технічних носіях для пред’явлення понятим. 
Висновки. За умови дотримання запропонованої процедури буде забезпечено і особисту безпеку учасників, і процесуальну форму обшуку житла чи іншого володіння. Також доцільним $\epsilon$ впровадження дистанційної участі понятих за допомогою застосування технічних засобів фіксації у режимі відеоконференції під час виявлення предметів обшуку у важкодоступних місцях.

Сучасні засоби криміналістичної техніки дають змогу оперативно, в межах обшуку виявляти вибухівку, радіоактивні, хімічні та ядерні матеріали у різних схованках. Зокрема, сьогодні під час обшуку використовуються такі засоби:

- настільні та портативні детектори, здатні виявляти та ідентифікувати вибухівку або наркотик - “IONSCAN 500DT", "IONSCAN 400B", “SABRE 5000", "MMTD” та інші;

- портативні прилади для виявлення отруйних речовин і токсичних промислових відходів - "CAM", "GID-3", "LCD 3.3", "SABRE 5000", "MMTD” та інші;

- прилади для визначення небезпечних хімічних речовин - “GasID”, “GUARDION”, "HazMatID Elite", "RESPONDER RCI" та інші [5].

Враховуючи вищевикладене, звертає на себе увагу й недостатня організація взаємодії між суб' єктами досудового розслідування з відповідними спеціалістами, а також підприємствами, установами та організаціями, зокрема, щодо порядку оплати їхньої допомоги на стадії досудового розслідування.

\section{Список використаних джерел:}

1.Кримінальний процесуальний кодекс України : Закон України від 13 квітня 2012 р. № 4651-VI. URL: http://zakon0.rada.gov.ua/laws/show/4651-17/paran5253\#n5253 (дата звернення: 20.08.2019).

2.Про затвердження Інструкції про поводження з вибуховими матеріалами в органах i підрозділах внутрішніх справ України : Наказ MBC України від 9 липня 2014 р. № 653. URL: https://zakon.rada.gov.ua/laws/show/z0870-14 (дата звернення: 20.08.2019).

3.Про затвердження Інструкції про порядок дій органів (підрозділів) поліції в разі виявлення радіоактивних, хімічних та ядерних матеріалів або отримання інформації про порушення правил чи незаконне поводження з ними : Наказ MBC від 6 вересня 2017 р. № 754. URL: https://zakon.rada.gov.ua/laws/show/z1240-17 (дата звернення: 20.08.2019).

4.Про затвердження Інструкції про порядок залучення працівників органів досудового розслідування поліції та Експертної служби Міністерства внутрішніх справ України як спеціалістів для участі в проведенні огляду місця події : Наказ МВС України від 3 листопада 2015 р. № 1339. URL: https://zakon.rada.gov.ua/laws/card/z1392-15 (дата звернення: 20.08.2019).

5.Версія : вебсайт. URL: https://www.versiya.com/ua/smiths-detection/radiation-detection.html.

6.Даніч Є.О. Використання спеціальних знань під час проведення слідчого експерименту : дис. .... канд. юрид. наук : 12.00.09. Київ, 2018. 238 с.

7.Коновалова В.О. Вбивство: мистецтво розслідування : монографія. Харків, 2001. 311 с.

8.Максимчук I.M., Сура O.М., Саковський А.А., Фурман Я.В. та ін. Дії поліції під час виявлення фактів незаконного поводження з небезпечними матеріалами : методичні рекомендації. Київ : Нац. акад. внутр. справ, 2019. 81 с.

9.Орлова Т.А. Особливості початкового етапу розслідування кримінальних правопорушень, пов'язаних із вибухами, загрозою вибухів або виявленням вибухових пристроїв. Підприємниитво, господарство і право. 2018. № 12. С. 327-331.

10. Поліщук І.Ю. Розслідування незаконного використання торговельних марок : дис. ... канд. юрид. наук : 12.00.09. Київ, 2019. 310 с.

11. Тимофєєва Н.В. Використання спеціальних знань при розслідуванні злочинів проти безпеки виробництва : дис. ... канд. юрид. наук : 12.00.09. Київ, 2018. 214 с. 